\title{
PENGARUH ASUPAN ZAT GIZI DAN JAMU PELANCAR AIR SUSU IBU (ASI) TERHADAP KADAR ZAT BESI (Fe) ASI IBU MENYUSUI
}

\section{The Effect of Maternal Nutritional Intake in Breastfeeding and Galactogogum Jamu on Breastmilk Iron (Fe) Level}

\author{
Enggar Wijayanti ${ }^{1 *}$, Zuraida Zulkarnain ${ }^{1}$ \\ 'Balai Besar Penelitian dan Pengembangan Tanaman Obat dan Obat Tradisional \\ Jalan Raya Lawu Nomor 11 Tawangmangu, Karanganyar, Jawa Tengah, Indonesia \\ *e-mail: enggarwj.189@gmail.com
}

Submitted: October $9^{\text {th }}, 2020$, revised: November 11 th, 2020 , approved: May 30th 2021

\begin{abstract}
Background. Breast milk contains macronutrients and micronutrients that are critical for newborns. Iron ( $F e)$ is a vital micronutrient found in breast milk. The mother's diet has a significant impact on her physiological response to breastfeeding. Maternal food intake during breastfeeding and galactogogum jamu administration has been believing related to Fe levels in breastmilk. Objective. This study aims to determine the effect of maternal nutrition intake and galactogogum jamu on iron (Fe) levels in breastmilk. Method. This research is a cohort intervention study, conducted as part of the research "Clinical Observation of the Formula of Jamu Pelancar ASI" from March to December 2018. This research had done at the offices of six herbal medicine doctors in eks Karesidenan Surakarta. The participants were 34 breastfeeding mothers ranging in age from 17 to 40 years. Data on Fe levels in breast milk and maternal food consumption had collected on the first day of treatment (day 0) and 28 days later (day 28). Food consumption data were gathered through interviews using a 2x24 hour food recall form administered on one weekday (Monday-Friday) and one weekend (Saturday-Sunday). The Nutrisurvey 2007 program had used to analyze additional data. Results. The results showed that the level of energy, protein, fat, carbohydrate, iron, and zinc consumption except for vitamin $C$ from subjects was lower than the nutritional adequacy rate (RDA) for breastfeeding mothers. The Wilcoxon test revealed no significant difference in breastmilk iron levels before and after the intervention. There was no meaningful relationship between Fe levels in breast milk and maternal nutrient intake $(p>0.05)$ at the linear regression test. Conclusion. Maternal nutritional intake and galactogogum jamu have no significant effect on breastmilk iron levels.
\end{abstract}

Keywords: breastfeeding mothers, breastmilk, iron levels, nutrition intake

\begin{abstract}
ABSTRAK
Latar Belakang. Air susu ibu (ASI) mengandung makronutrien dan mikronutrien yang sangat penting bagi bayi yang baru lahir. Salah satu mikronutrien penting yang terdapat dalam ASI adalah zat besi $(\mathrm{Fe})$. Asupan makanan ibu selama menyusui dan pemberian jamu pelancar ASI diduga berpengaruh terhadap kadar Fe pada ASI yang dihasilkan. Tujuan. Penelitian ini bertujuan mengetahui pengaruh zat gizi (makronutrien dan mikronutrien) dari makanan yang dikonsumsi oleh ibu dan pemberian jamu pelancar ASI dengan kandungan Fe dalam ASI. Metode. Penelitian ini merupakan penelitian kohort intervensi dan merupakan bagian dari penelitian "Observasi Klinik Formula Jamu Pelancar Air Susu Ibu (ASI)" yang dilakukan selama bulan Maret sampai Desember 2018. Penelitian ini dilakukan di tempat praktik enam orang dokter Saintifikasi Jamu (SJ) di wilayah eks Karesidenan Surakarta. Subjek merupakan ibu menyusui berjumlah 34 orang berusia 17-40 tahun. Data kadar Fe dalam ASI dan konsumsi makanan ibu diambil pada hari sebelum perlakuan (hari ke-0) dan setelah 28 hari pemberian jamu pelancar ASI (hari ke-28). Data konsumsi makanan dikumpulkan melalui wawancara menggunakan formulir food recall
\end{abstract}


2x24 jam yang diambil pada satu hari kerja (Senin-Jumat) dan satu hari di akhir pekan (SabtuMinggu). Data selanjutnya, dianalisis dengan program Nutrisurvey 2007. Hasil. Penelitian ini mendapatkan tingkat konsumsi energi, protein, lemak, karbohidrat, zat besi, dan seng kecuali vitamin C dari subjek lebih rendah dari Angka Kecukupan Gizi (AKG) untuk ibu menyusui. Hasil uji Wilcoxon menunjukkan tidak ada perbedaan kadar Fe ASI sebelum dan sesudah perlakuan. Hasil uji regresi linier menunjukkan tidak ada hubungan yang bermakna antara kadar Fe dalam ASI dengan asupan zat gizi ibu $(p>0,05)$. Kesimpulan. Asupan gizi ibu dan pemberian jamu pelancar ASI tidak berpengaruh terhadap kadar Fe dalam ASI.

Kata kunci: ibu menyusui, ASI, kadar zat besi, asupan gizi

\section{PENDAHULUAN}

Air susu ibu (ASI) merupakan sumber nutrisi terbaik dan optimal bagi bayi. ${ }^{1,2}$ Kualitas maupun kuantitas ASI yang diproduksi oleh ibu yang sehat dan memiliki status gizi yang baik dapat memberikan nutrisi dan komponen bioaktif yang cukup untuk 4-6 bulan pertama kehidupan bayi. ${ }^{3}$ Oleh karena itu, penting untuk memberikan ASI eksklusif selama enam bulan. ${ }^{1}$ ASI terdiri atas komponen gizi dan non gizi. ${ }^{4}$ Komponen gizi diantaranya makronutrien dan mikronutrien yang meliputi karbohidrat, protein, lemak, vitamin, dan mineral. Kuantitas ASI dan komposisi nutrien yang diproduksi akan berbeda untuk setiap ibu bergantung pada kebutuhan bayi. Kandungan zat gizi ASI awal dan akhir pada setiap ibu yang menyusui juga berbeda. ${ }^{2}$ Perbedaan kuantitas ASI dan komposisi di atas juga terlihat pada periode menyusui (kolostrum, ASI transisi, ASI matang, dan ASI pada saat penyapihan). ${ }^{5}$ Pola makan ibu memiliki peran penting dalam respon fisiologis terhadap proses menyusui. Zat gizi dari makanan yang diserap oleh ibu menyusui berhubungan dengan kuantitas dan kualitas ASI yang dihasilkan. ${ }^{6}$ Salah satu mikronutrien penting yang terdapat dalam ASI adalah zat besi (Fe). Kandungan zat besi (Fe) dalam ASI sangat vital bagi kelangsungan hidup bagi bayi yang baru lahir. ${ }^{7}$ Terdapat beberapa penelitian yang menyebutkan buruknya intake zat gizi mikro dan status gizi mikro ibu menyusui berakibat pada rendahnya kadar zat gizi mikro dalam ASI. Penelitian baik di dalam maupun di luar negeri menunjukkan bahwa kadar zat besi dalam ASI sangat bervariasi. Ditemukannya prevalensi anemia pada bayi yang cukup tinggi, kemungkinan besar disebabkan oleh sumber nutrisi ASI yang mengalami kekurangan komponen nutrien. ${ }^{8} \mathrm{Di}$ Indonesia angka prevalensi anemia pada bayi berumur kurang dari 6 bulan masih cukup tinggi. ${ }^{9}$ Prevalensi anemia defisiensi besi (ADB) yang pernah dilaporkan pada bayi 0-6 bulan sebesar 61,3 persen, pada bayi $6-12$ bulan sebesar 64,8 persen. ${ }^{10}$ Sedangkan insidensi ADB pada balita 40,5 persen. ${ }^{11}$ Penelitian kohort yang dilakukan terhadap 211 bayi berusia 0 bulan selama 6 bulan dan 12 bulan didapatkan insiden ADB sebesar 40,8 persen dan 47,4 persen. ${ }^{10}$ Kebutuhan besi bagi bayi tergantung pada kandungan besi dari ASI. Penelitian Zuraida et al. tahun 2016 melaporkan bahwa pemberian jamu pelancar ASI berpengaruh secara signifikan terhadap produksi volume ASI dan kenaikan berat badan bayi, namun dalam penelitian tersebut belum dilakukan pengukuran pengaruh konsumsi jamu terhadap kadar Fe dalam ASI maupun kadar $\mathrm{Hb}$ dari subjek ibu menyusui. Penelitian ini merupakan studi pendahuluan yang bertujuan 
untuk mengetahui pengaruh asupan gizi ibu yang mengonsumsi jamu pelancar ASI tehadap kadar zat besi (Fe) dalam ASI.

\section{METODE}

Penelitian ini adalah penelitian kohort intervensi dengan design one group pre and post test dan merupakan bagian dari penelitian payung "Observasi Klinik Formula Jamu Pelancar Air Susu Ibu (ASI)" yang dilakukan selama bulan Maret hingga Desember 2018. Penelitian ini dilakukan di tempat praktik dokter Saintifikasi Jamu (SJ) yang berjumlah enam orang yang berlokasi di wilayah eks Karesidenan Surakarta. Populasi penelitian ini adalah 60 orang ibu menyusui yang merupakan subjek penelitian payung "Observasi Klinis Jamu Pelancar ASI". Sampel penelitian diambil dengan menggunakan teknik purposive sampling sesuai dengan kriteria inklusi, meliputi ibu menyusui dengan usia 17-40 tahun; tidak sedang menderita penyakit berat seperti diabetes melitus, asma, jantung, epilepsi, dan hipertensi; memiliki bayi yang sedang disusui berusia 1-4 bulan dalam kondisi normal dan sehat; serta bersedia mengikuti jadwal penelitian sampai selesai dan menandatangani informed consent.

Variabel penelitian yang dianalisis meliputi kadar hemoglobin $(\mathrm{Hb})$, kadar zat besi ( $\mathrm{Fe}$ ) dalam ASI, status gizi menurut Indeks Massa Tubuh (IMT) ibu serta konsumsi makanan ibu menyusui pada hari sebelum dilakukan perlakuan (hari ke-0) dan setelah 28 hari dilakukan perlakuan (hari ke-28). Analisis data kadar $\mathrm{Hb}$ dan kadar Fe dalam ASI dilakukan oleh Laboratorium PT. "P". Kadar Hb dalam darah ibu dianalisis dengan menggunakan alat Hematology Analyzer yang sudah terstandarisasi, sedangkan kadar Fe dianalisis dengan menggunakan alat Inductively coupled plasma-mass spectrometry $7700 x$. Hasil pengukuran kadar $\mathrm{Hb}$ selanjutnya dikategorikan menjadi anemia ringan ( $\mathrm{Hb} 11,0-11,9 \mathrm{mg} / \mathrm{dL})$ dan anemia sedang ( $\mathrm{Hb} 8,0-10,9 \mathrm{mg} / \mathrm{dL}){ }^{12,13}$ Data konsumsi makanan ibu menyusui dikumpulkan melalui wawancara menggunakan formulir food recall 2x24 jam yang diambil pada satu hari kerja (Senin-Jumat) dan satu hari di akhir pekan (Sabtu-Minggu). Data konsumsi makanan dianalisis menggunakan program Nutrisurvey 2007 untuk mengetahui kandungan zat gizinya dan selanjutnya dirata-rata. Data konsumsi makanan subjek juga dibandingkan dengan angka kecukupan gizi (AKG) dan dikategorikan menjadi konsumsi kurang ( $<80 \%$ AKG) dan cukup ( $\geq 80 \%$ AKG). Status gizi subjek ditentukan berdasarkan penghitungan IMT selanjutnya dikategorikan menjadi kurus (IMT<18,5 kg/m²), normal (IMT 18,5-22,9 kg/m²), gemuk (IMT 23,0-24,9 kg/m²), obesitas I (IMT 25,0-29,9 kg/ $\left.\mathrm{m}^{2}\right)$, dan obesitas II (IMT $\left.\geq 30,0 \mathrm{~kg} / \mathrm{m}^{2}\right){ }^{14}$

Seluruh data yang diperoleh selanjutnya diolah dan dianalisis secara statistik dengan menggunakan software SPSS 25. Berdasarkan hasil uji Saphiro Wilk, apabila data berdistribusi normal akan dilakukan uji t berpasangan namun apabila data tidak berdistribusi normal akan dilakukan uji Wilcoxon untuk mengetahui signifikansi perbedaan kadar Fe dalam ASI sebelum (hari ke-0) dan sesudah perlakuan (hari ke-28). Analisis bivariat dengan uji regresi linier sederhana dilakukan untuk mengetahui pengaruh variabel confounding (rerata IMT, kadar $\mathrm{Hb}$, asupan zat gizi) terhadap variabel terikat kadar Fe dalam ASI pada H-28. Selanjutnya 
akan dilakukan uji multivariat regresi linier ganda terhadap variabel confounding apabila terdapat nilai signifikan dari hasil analisis bivariat tersebut.

Subjek ibu menyusui diberikan formula jamu pelancar ASI yang terdiri atas daun katuk, daun bangun-bangun, dan daun pepaya yang berbentuk simplisia dengan dosis tertentu. Simplisia tersebut direbus dengan empat gelas belimbing ( $\pm 800 \mathrm{cc})$ selama $15-20$ menit hingga air tinggal dua gelas $( \pm 400 \mathrm{cc})$ dan diminum masing-masing satu gelas pada pagi dan sore hari. Kepatuhan atau kedisiplinan subjek dalam mengonsumsi jamu dipantau oleh tim peneliti dan dicatat pada form pemantauan yang sudah disediakan. Pada akhir minggu kedua dilakukan evaluasi ada tidaknya efek samping setelah mengonsumsi jamu. Pemberian jamu pelancar ASI pada subjek dihentikan apabila muncul keluhan efek samping akibat mengonsumsi jamu seperti mual, muntah, diare, sakit perut, kenaikan nilai enzim SGOT, SGPT, ureum, dan kreatinin yang melebihi nilai normal. Studi ini merupakan bagian dari penelitian payung "Observasi Klinik Formula Jamu Pelancar Air Susu Ibu (ASI)" yang telah mendapatkan persetujuan etik dari Komisi Etik Penelitian Kesehatan Badan Penelitian dan Pengembangan Kesehatan dengan nomor LB.02.01/2/KE. 248/2018.

\section{HASIL}

Pada penelitian ini diperoleh jumlah subjek yang memenuhi kriteria sampel sebanyak 34 orang. Rata-rata umur subjek ibu menyusui adalah 29,00 $\pm 5,97$ tahun. Subjek ibu menyusui memiliki rata-rata IMT masingmasing sebesar $24,01 \pm 3,09 \mathrm{~kg} / \mathrm{m}^{2}$ pada hari ke-0 (sebelum perlakuan) dan $24,19 \pm 3,14 \mathrm{~kg} /$ $\mathrm{m}^{2}$ hari ke-28 (setelah perlakuan). Rata-rata kadar $\mathrm{Hb}$ subjek sebelum perlakuan sebesar $13,51 \pm 1,48 \mathrm{~g} / \mathrm{dL}$, dan setelah perlakuan sebesar 13,1 $\pm 1,25 \mathrm{~g} / \mathrm{dL}$. Rata-rata kadar zat

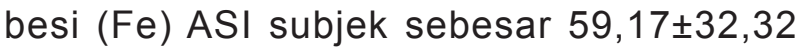
pada hari ke-0 dan menjadi $50,31 \pm 20,14$ $(\mu \mathrm{g} / \mathrm{L})$ pada hari ke-28. Karakteristik subjek berdasarkan umur, IMT, kadar Hb, dan Fe ASI sebelum perlakuan (hari ke-0) dan sesudah perlakuan (hari ke-28) dapat dilihat dalam Tabel 1 di bawah ini.

Tabel 1. Karakteristik Subjek Berdasarkan Rerata Umur, IMT, Kadar Hb, dan Fe ASI pada Hari ke-0 dan Hari ke-28

\begin{tabular}{lccccc}
\hline \multirow{2}{*}{ Karakteristik } & \multicolumn{2}{c}{ Hari ke-0 } & & \multicolumn{2}{c}{ Hari ke-28 } \\
& Mean & Std. Deviation & & Mean & Std. Deviation \\
\cline { 2 - 3 } \cline { 5 - 6 } & 29,00 & $\pm 5,97$ & & 29,00 & $\pm 5,97$ \\
Umur (tahun) & 24,01 & $\pm 3,09$ & & 24,19 & $\pm 3,14$ \\
IMT (kg/m $\left.{ }^{2}\right)$ & 13,51 & $\pm 1,48$ & & 13,1 & $\pm 1,25$ \\
$\mathrm{Hb}(\mathrm{g} / \mathrm{dL})$ & 59,17 & $\pm 32,32$ & & 50,31 & $\pm 20,14$ \\
Fe ASI $(\mu \mathrm{g} / \mathrm{L})$ & & & &
\end{tabular}


Pada Tabel 1 dan Tabel 2 diketahui rerata konsumsi zat gizi ibu menyusui pada hari ke-0 (sebelum perlakuan) dan hari ke-28 (sesudah perlakuan). Konsumsi zat gizi meliputi energi, protein, lemak, zat besi, vitamin C, dan seng. Rerata konsumsi energi pada hari ke- 0 sebesar $1684,68 \pm 312,91 \mathrm{Kkal}$, sedangkan pada hari ke28 sedikit mengalami kenaikan dengan rerata sebesar $1716,18 \pm 332,52$ Kkal. Konsumsi protein dan lemak juga mengalami sedikit kenaikan bila dibandingkan dengan sebelum perlakuan yakni dengan selisih rerata sebesar $5,38 \mathrm{~g}$ untuk protein dan 5,19 g untuk lemak. Tingkat konsumsi karbohidrat, zat besi, dan vitamin C pada subjek mengalami penurunan pada hari ke28 jika dibandingkan hari ke-0. Rerata konsumsi karbohidrat subjek pada sebelum perlakuan sebesar $239,29 \pm 52,16$ g menjadi $233,24 \pm 54,24$ g setelah 28 hari perlakuan. Zat besi $(\mathrm{Fe})$ $10,04 \pm 3,08 \mathrm{mg}$ menjadi $9,88 \pm 3,13 \mathrm{mg}$. Rerata konsumsi vitamin C sebesar 121,19 $\pm 76,99 \mathrm{mg}$ pada hari ke- 0 dan $117,79 \pm 79,17$ mg pada hari ke-28. Konsumsi seng ( $\mathrm{Zn}$ ) subjek mengalami sedikit kenaikan pada hari ke-28 dibandingkan hari ke-0.

Tabel 2. Rerata Konsumsi Zat Gizi Subjek pada Hari ke-0 dan Hari ke-28

\begin{tabular}{lccccc}
\hline \multirow{2}{*}{ Zat Gizi } & \multicolumn{2}{c}{ Hari ke-0 } & & \multicolumn{2}{c}{ Hari ke-28 } \\
& Mean & Std. Deviation & & Mean & Std. Deviation \\
\cline { 2 - 3 } \cline { 5 - 6 } \cline { 5 - 6 } & 1684,68 & $\pm 312,91$ & & 1716,18 & $\pm 332,52$ \\
Energi (Kkal) & 53,39 & $\pm 13,02$ & & 58,77 & $\pm 13,69$ \\
Protein (g) & 57,65 & $\pm 13,51$ & & 62,84 & $\pm 12,89$ \\
Lemak (g) & 239,29 & $\pm 52,16$ & & 233,24 & $\pm 54,24$ \\
Karbohidrat (g) & 10,04 & $\pm 3,08$ & & 9,88 & $\pm 3,13$ \\
Zat besi (mg) & 121,19 & $\pm 76,99$ & & 117,79 & $\pm 79,17$ \\
Vitamin C (mg) & 6,36 & $\pm 1,69$ & & 6,69 & $\pm 1,92$ \\
Seng (mg) & & & & &
\end{tabular}

Diketahui hampir seluruh subjek $(97,1 \%)$ memiliki kadar $\mathrm{Hb}$ normal baik pada hari ke-0 maupun hari ke-28. Status gizi subjek berdasarkan IMT sebagian besar mengalami obesitas I $(38,2 \%)$ baik pada hari ke-0 maupun setelah 28 hari perlakuan, diikuti status gizi normal $(29,4 \%)$ pada hari ke-0 dan 32,4 persen pada hari ke-28. Terdapat satu orang subjek yang awalnya berstatus gizi gemuk sebelum perlakuan berubah menjadi normal setelah perlakuan. Berdasarkan zat gizi yang dikonsumsi subjek, lebih dari tiga perempat subjek memiliki tingkat konsumsi energi, protein, karbohidrat, zat besi, dan seng dengan kategori kurang dibandingkan dengan AKG baik pada hari ke-0 maupun setelah hari ke-28. Namun terdapat sedikit kenaikan persentase pada hari ke-28 jika dibandingkan dengan hari ke-0. Tingkat konsumsi lemak dari subjek lebih dari separuhnya tergolong cukup, baik sebelum maupun setelah perlakuan. Distribusi frekuensi subjek menurut status anemia, status gizi, dan konsumsi zat gizi sebelum (hari ke-0) dan sesudah perlakuan (hari ke-28) dapat dilihat pada Tabel 3 berikut ini. 
Tabel 3. Distribusi Frekuensi Subjek menurut Status Anemia, Status Gizi dan Konsumsi Zat Gizi Hari ke-0 dan Hari ke-28

\begin{tabular}{|c|c|c|c|c|c|}
\hline \multirow{2}{*}{ Variabel } & \multirow{2}{*}{ Kategori } & \multicolumn{2}{|c|}{ Hari ke-0 } & \multicolumn{2}{|c|}{ Hari ke-28 } \\
\hline & & $\mathrm{n}$ & $\%$ & $\mathrm{n}$ & $\%$ \\
\hline \multirow{2}{*}{ Status anemia menurut kadar $\mathrm{Hb}$} & Anemia ringan & 1 & 2,9 & 1 & 2,9 \\
\hline & Normal & 33 & 97,1 & 33 & 97,1 \\
\hline \multirow{5}{*}{ Status gizi menurut IMT } & Kurus & 1 & 2,9 & 1 & 2,9 \\
\hline & Normal & 10 & 29,4 & 11 & 32,4 \\
\hline & Gemuk & 9 & 26,5 & 8 & 23,5 \\
\hline & Obesitas I & 13 & 38,2 & 13 & 38,2 \\
\hline & Obesitas II & 1 & 2,9 & 1 & 2,9 \\
\hline \multicolumn{6}{|l|}{ Konsumsi zat gizi } \\
\hline \multirow{2}{*}{ Energi } & Kurang & 29 & 85,29 & 27 & 79,41 \\
\hline & Cukup & 5 & 14,71 & 7 & 29,59 \\
\hline \multirow{2}{*}{ Protein } & Kurang & 26 & 76,47 & 23 & 67,65 \\
\hline & Cukup & 8 & 23,53 & 11 & 32,35 \\
\hline \multirow{2}{*}{ Lemak } & Kurang & 12 & 35,29 & 7 & 20,59 \\
\hline & Cukup & 22 & 64,71 & 27 & 79,41 \\
\hline \multirow{2}{*}{ Karbohidrat } & Kurang & 31 & 91,18 & 30 & 88,24 \\
\hline & Cukup & 3 & 8,82 & 4 & 11,74 \\
\hline \multirow{2}{*}{ Zat besi (Fe) } & Kurang & 32 & 94,12 & 30 & 88,24 \\
\hline & Cukup & 2 & 5,88 & 4 & 11,76 \\
\hline \multirow{2}{*}{ Vitamin C } & Kurang & 16 & 47,06 & 19 & 55,88 \\
\hline & Cukup & 18 & 52,94 & 15 & 44,12 \\
\hline \multirow{2}{*}{ Seng $(Z n)$} & Kurang & 34 & 100 & 32 & 94,12 \\
\hline & Cukup & 0 & 0 & 2 & 5,88 \\
\hline
\end{tabular}

Dalam menentukan signifikansi perbedaan kadar zat besi ( $\mathrm{Fe}$ ) sebelum dan sesudah pemberian ramuan jamu dilakukan dengan uji Wilcoxon karena berdasarkan hasil uji normalitas Saphiro-Wilk menunjukkan data kadar Fe ASI tidak berdistribusi normal $(p=0,000)$. Hasil uji Wilcoxon nilai $p=0,343$ yang berarti tidak ada perbedaan signifikan rerata kadar zat besi $(\mathrm{Fe})$ ASI sebelum dan sesudah pemberian jamu (Tabel 4).

Tabel 4. Hasil Uji Wilcoxon Zat Besi (Fe) dalam ASI

\begin{tabular}{lcccc}
\hline Waktu Perlakuan & $\mathrm{n}$ & Rerata Fe ASI $(\mu \mathrm{g} / \mathrm{L})$ & Standar Deviasi & $p^{*}$ \\
\hline Hari ke-0 & 34 & 59,17 & 32,32 & 0,343 \\
Hari ke-28 & 34 & 50,31 & 20,14 & \\
\hline
\end{tabular}

*Derajat kepercayaan 95\% 
Pemberian ramuan jamu bukan merupakan variabel tunggal yang diasumsikan dapat memengaruhi kadar zat besi (Fe) dalam ASI melainkan variabel lain seperti IMT, kadar $\mathrm{Hb}$, dan asupan zat gizi ibu menyusui juga diasumsikan turut berpengaruh terhadap kadar Fe dalam ASI.

Tabel 5. Hasil Uji Bivariat Regresi Linier Variabel Confounding Hari ke-28

\begin{tabular}{|c|c|c|c|c|c|}
\hline \multirow{2}{*}{ Variabel } & \multirow{2}{*}{ B } & \multirow{2}{*}{ Std. Error } & \multirow{2}{*}{ Sig. } & \multicolumn{2}{|c|}{$95 \% \mathrm{Cl}$} \\
\hline & & & & bawah & atas \\
\hline IMT & $-0,227$ & 1,135 & 0,843 & $-2,538$ & 2,084 \\
\hline Kadar $\mathrm{Hb}$ & $-2,543$ & 2,817 & 0,373 & $-8,282$ & 3,195 \\
\hline Asupan protein & $-0,017$ & 0,260 & 0,947 & $-0,547$ & 0,512 \\
\hline Asupan lemak & $-0,025$ & 0,276 & 0,929 & $-0,587$ & 0,538 \\
\hline Asupan karbohidrat & 0,006 & 0,066 & 0,930 & $-0,128$ & 0,139 \\
\hline Asupan zat besi (Fe) & $-0,119$ & 1,138 & 0,917 & $-2,437$ & 2,198 \\
\hline Asupan vitamin C & $-0,038$ & 0,044 & 0,397 & $-0,129$ & 0,052 \\
\hline Asupan seng (Zn) & 1,748 & 1,831 & 0,347 & $-1,981$ & 5,477 \\
\hline
\end{tabular}

Hasil analisis secara bivariat dengan uji regresi linier menunjukkan tidak terdapat hubungan yang signifikan $(p>0,05)$ antara variabel confounding yang terdiri dari IMT, kadar $\mathrm{Hb}$, asupan protein, lemak, karbohidrat, zat besi, vitamin $\mathrm{C}$, dan seng ibu dengan kadar zat besi dalam ASI (Tabel 5) sehingga tidak dilanjutkan uji analisis secara multivariat.

\section{PEMBAHASAN}

Produksi ASI merupakan proses yang kompleks yang dipengaruhi oleh banyak faktor, diantaranya usia, paritas, status gizi, dan asupan makanan ibu. ${ }^{6}$ Kondisi ibu juga berperngaruh terhadap ASI yang diproduksi. ${ }^{4}$ Pada penelitian ini kadar zat besi $(\mathrm{Fe})$ rata-rata dalam ASI sebesar $59,17 \pm 32,32 \mu \mathrm{g} / \mathrm{L}(0,05917 \pm 0,03232 \mathrm{mg} / \mathrm{L})$ hari ke-0 dan 50,31 $\pm 20,14 \mu \mathrm{g} / \mathrm{L}(0,05031 \pm 0,02014$ $\mathrm{mg} / \mathrm{L}$ ) dimana angka ini lebih rendah apabila dibandingkan dengan sejumlah penelitian yang menyebutkan kadar zat besi rata-rata dalam ASI sebesar 5-16 $\mu \mathrm{M}$ (0.27-0.90 mg/L). ${ }^{15}$ Literatur lainnya menyebutkan bahwa kadar besi ASI ratarata sebesar $(0,1-1,6 \mathrm{mg} / \mathrm{L})$ pada semua tahap laktasi. ${ }^{16,17}$ Kadar Fe dalam ASI subjek semakin menurun pada hari ke-28 bila dibandingkan dengan hari ke-0. Hal ini sesuai dengan penelitian yang menyebutkan bahwa konsentrasi zat besi dalam ASI bervariasi selama masa menyusui dan tertinggi pada awal menyusui dan terus menurun selama periode menyusui. ${ }^{17}$ Studi lainnya menyebutkan bahwa kandungan $\mathrm{Fe}$ pada kolostrum lebih tinggi dibandingkan ASI transisi maupun ASI matur. ${ }^{18}$ Berturut-turut kadar Fe ASI tertinggi terdapat dalam ASI kolostrum rata-rata sebesar $1,0 \mathrm{mg} / \mathrm{L}$, pada $A S I$ matur 0,20-0,80 mg/L, sedangkan pada ASI transisi awal sebesar 0,97 mg/L. ${ }^{16}$ Studi lain disebutkan bahwa kandungan zat besi, tembaga, dan seng pada ASI mengalami penurunan antara periode 2 minggu hingga 5 sampai 9 bulan masa laktasi. ${ }^{19}$ Kadar Fe ASI subjek rata-rata hanya 
setengah dari kadar besi yang dianjurkan $\mathrm{WHO}$, yakni sebesar $0,5 \mathrm{mg} / \mathrm{L}$. Hal ini dimungkinkan terjadi karena diet dan konsumsi zat besi dari ibu menyusui yang lebih rendah dari AKG yang dianjurkan. ${ }^{8}$ Kandungan zat gizi ASI dipengaruhi oleh diet ibu dan lamanya menyusui. Komposisi zat gizi ASI akan berubah menyesuaikan dengan kebutuhan bayi, dimana hal ini merupakan proses yang berlangsung secara alamiah. ${ }^{19}$ Kadar Fe ASI ibu menyusui dalam penelitian ini belum dapat mewakili kondisi di seluruh Indonesia karena terbatasnya jumlah sampel. Namun temuan ini dapat menjadi awal untuk dilakukannya pemeriksaan serupa pada ibu menyusui di Indonesia mengingat pentingnya Fe untuk perkembangan bayi.

Hasil penelitian ini menunjukkan bahwa rata-rata subjek ibu menyusui memiliki status gizi lebih (IMT $\geq 23 \mathrm{~kg} / \mathrm{m}^{2}$ ). Hasil uji statistik pada penelitian ini menunjukkan tidak terdapat hubungan antara status gizi ibu menyusui dengan kadar zat besi dalam ASI. Studi di Amerika Serikat melaporkan bahwa tidak ada hubungan status gizi ibu sebelum dan sesudah melahirkan dengan volume ASI yang dihasilkan, namun belum ada data penelitian mengenai kandungan nutrisi dalam ASI. ${ }^{20}$ Penelitian lain menyebutkan bahwa perubahan status gizi ibu yang mengubah komposisi ASI dapat berdampak positif, netral atau negatif terhadap bayi yang disusui. ${ }^{19}$ Penelitian longitudinal yang dilakukan pada ibu satu bulan dan empat bulan setelah melahirkan menyebutkan bahwa status gizi tidak berhubungan dengan proses laktasi. ${ }^{21}$ Beberapa penelitian menyebutkan bahwa konsentrasi zat gizi dalam ASI tidak sensitif terhadap perubahan pola makan dan status gizi ibu. ${ }^{22}$ Hasil penelitian ini berbeda dengan Nikniaz et al. yang menyebutkan terdapat hubungan negatif yang signifikan antara kadar Fe dalam ASI dengan IMT ibu. ${ }^{23,24}$ Sedangkan Chierici et al. menyebutkan bahwa konsentrasi Fe menurun seiring dengan kenaikan IMT ibu. ${ }^{6,24}$ Penelitian Kumar et al. menyebutkan bahwa status gizi ibu berpengaruh secara signifikan terhadap status zat besi janin, namun hanya sedikit berpengaruh terhadap kandungan zat besi dalam ASI. ${ }^{25}$

Pada penelitian ini diketahui rerata kadar $\mathrm{Hb}$ ibu menyusui yang menjadi subjek masih dalam kategori normal. Dari 34 subjek hanya satu orang yang mengalami anemia ringan $(\mathrm{Hb}<12 \mathrm{~g} /$ $\mathrm{dL})$. Ibu menyusui yang mengalami anemia akan berdampak pada kemampuan memproduksi ASI dalam jumlah yang cukup yang pada akhirnya akan berpengaruh terhadap status gizi bayi yang disusui. ${ }^{4}$ Dalam jangka panjang berakibat terjadinya hambatan pertumbuhan anak usia 3-15 bulan. ${ }^{26}$ Hasil uji statistik menunjukkan tidak ada hubungan antara kandungan Fe dalam ASI dengan kadar $\mathrm{Hb}$ maupun status anemia pada ibu menyusui $(p>0,05)$. Hal ini sesuai dengan penelitian yang dilakukan di India yang menunjukkan bahwa tidak terdapat perbedaan signifikan antara kandungan zat besi pada ibu menyusui yang mengalami anemia maupun tidak anemia. Penelitian lain menyebutkan tidak ada hubungan antara kandungan $\mathrm{Fe}$ dalam ASI dengan kadar $\mathrm{Hb}$ ibu baik pada saat lahir maupun setelah berusia enam bulan. ${ }^{17}$ Selain itu tidak ada hubungan antara kandungan $\mathrm{Fe}$ dalam ASI dengan status Fe ibu. ${ }^{4,20,27}$ Meski demikian terdapat laporan bahwa rata-rata ibu yang mengalami anemia mengeluarkan lebih sedikit zat besi dan laktoferin dalam ASI yang mereka produksi. Penelitian Kumar et al. menyebutkan bahwa kandungan zat besi ASI 
berkurang secara signifikan pada ibu yang mengalami anemia berat, namun tidak pada ibu yang mengalami anemia ringan hingga sedang. ${ }^{25}$ Namun beberapa studi yang dilakukan pada wanita menyusui dari berbagai etnis menunjukkan bahwa zat besi dalam ASI tidak tergantung pada status $\mathrm{Hb}$ dan kadar zat besi ibu. Kadar zat besi dan laktoferin ASI diketahui bervariasi sesuai dengan jenis susu, usia menyusui dan variasi diurnal. ${ }^{17}$ Pada penelitian ini rerata persentase asupan energi subjek bila dibandingkan AKG yang dianjurkan naik dari 67 persen pada hari ke-0 menjadi 68 persen pada hari ke-28. Sedangkan persentase asupan protein meningkat dari 66 persen menjadi 73 persen dan rerata asupan lemak naik dari 89 persen menjadi 97 persen. Peningkatan rerata asupan ini kemungkinan disebabkan oleh ibu meminum rebusan formula jamu pelancar ASI yang mengandung daun pepaya yang dapat meningkatkan nafsu makan ibu menyusui. Meski mengalami peningkatan, namun secara keseluruhan rerata asupan energi, protein, lemak, dan karbohidrat dari subjek ibu menyusui masih lebih rendah dari AKG yang dianjurkan untuk ibu menyusui. Hasil uji statistik menunjukkan tidak ada hubungan antara tingkat asupan energi, protein, lemak, dan karbohidrat dengan kadar Fe di dalam ASI. Sesuai dengan penelitian Nikniaz et al. bahwa tidak ada hubungan antara asupan energi dengan kadar Fe dalam ASI. ${ }^{23}$ Penelitian yang dilakukan Khurana et al. di India juga menunjukkan bahwa tidak terdapat hubungan antara kandungan zat besi dalam ASI dengan diet ibu. ${ }^{17}$ Pada penelitian ini tingkat asupan zat besi subjek menurun dari 55,78 persen pada hari ke-0 menjadi 54,89 persen hari ke-28, demikian juga vitamin $C$ dari 100,99 persen menjadi 98,16 persen. Sedangkan asupan seng mengalami kenaikan 48,92 persen menjadi 51,46 persen. Tingkat konsumsi zat besi dan seng pada subjek masih kurang jika dibandingkan dengan AKG yang dianjurkan untuk ibu menyusui, namun subjek ibu menyusui masih memiliki kadar $\mathrm{Hb}$ yang normal. Hal ini sesuai dengan penelitian dari Asakura et al. yang menyebutkan bahwa tidak ada hubungan antara asupan makanan dan zat besi (Fe) terhadap terjadinya anemia pada 1019 wanita muda di Jepang yang berusia 18-25 tahun. Dalam kondisi asupan Fe kurang, vitamin $C$ dapat meningkatkan penyerapan Fe yang berasal dari sumber besi nonheme sehingga kebutuhan zat besi dalam tubuh tetap terpenuhi. ${ }^{28}$ Pada penelitian ini asupan vitamin C dari subjek ibu menyusui tergolong cukup sehingga dapat menjelaskan kondisi kadar $\mathrm{Hb}$ ibu menyusui yang masih dalam kategori normal.

Hasil uji statistik menunjukkan bahwa tidak ada hubungan antara asupan zat besi, seng, dan vitamin $\mathrm{C}$ dengan kandungan zat besi dalam ASI ibu. Hal ini sesuai dengan penelitian yang dilakukan oleh Villalpando et al. bahwa tidak ada hubungan antara asupan energi, zat besi, dan folat terhadap konsentrasi zat besi ASI. ${ }^{27}$ Literatur lain juga menyebutkan bahwa tidak terdapat hubungan antara asupan zat gizi mikro pada ibu dengan kadar zat gizi mikro pada ASI. ${ }^{4}$ Faktor-faktor yang mengatur konsentrasi zat besi dalam ASI belum sepenuhnya diketahui secara pasti, namun pada studi yang dilakukan oleh Sigman dan Lonnerdal disebutkan bahwa terdapat mekanisme kontrol homeostatis terhadap konsentrasi zat besi dalam ASI yakni melalui pengaturan jumlah reseptor transferin dalam kelenjar susu yang akan menyesuaikan saat terjadi defisiensi maupun kecukupan zat besi. ${ }^{17}$ 


\section{KESIMPULAN}

Asupan gizi ibu meliputi energi, protein, lemak, karbohidrat, zat besi, vitamin $\mathrm{C}$, dan seng serta konsumsi ramuan jamu pelancar ASI tidak berpengaruh terhadap kadar zat besi dalam ASI. Rata-rata tingkat konsumsi zat gizi ibu masih lebih rendah dibandingkan dengan AKG yang dianjurkan.

\section{SARAN}

Perlu penelitian lebih lanjut mengenai faktorfaktor yang berpengaruh langsung terhadap kadar Fe dalam ASI dan perlu pengukuran kadar zat besi pada bayi yang dihubungkan dengan kadar Fe pada ASI dan risiko anemia pada bayi ASI.

\section{UCAPAN TERIMA KASIH}

Ucapan terima kasih kepada Kepala Balai Besar Penelitian dan Pengembangan Tanaman Obat dan Obat Tradisional (B2P2TOOT) beserta semua staf, para peneliti dan rekan-rekan di Rumah Riset Jamu Hortus Medicus serta para subjek atas kerja samanya dalam penelitian ini.

\section{DAFTAR PUSTAKA}

1. Hannan MA, Faraji B, Tanguma J, Longoria N, Rodriguez RC. Maternal Milk Concentration of Zinc, Iron, Selenium, and lodine and Its Relationship to Dietary Intakes. Biol Trace Elem Res. 2009;127:6-15.

2. Ernawati D, Ismarwati, Hutapea HP. Analisis Kandungan Fe dalam Air Susu Ibu (ASI) pada Ibu Menyusui. J Ners dan Kebidanan. 2019;6(1):51-5.

3. Ardiny F, Rahayuni A. Hubungan Status Gizi Ibu dengan Status Gizi Bayi Usia 5-6 Bulan yang Mendapat ASI Ekslusif. J Nutr Coll. 2013;2(4):600-7.

4. Aritonang E. Pengaruh Pemberian Mie Instan Fortifikasi pada Ibu Menyusui terhadap Kadar Zink dan Besi ASI serta Pertumbuhan Linier Bayi. Disertasi. Bogor: Fakultas Ekologi Manusia Institut Pertanian Bogor, 2007.

5. Fly A. Minerals and Trace Elements in Milk. Advances in Food and Nutrition Research. 1992;36:209-52.

6. Chierici R, Saccomandi D, Vigi V. Dietary Supplements for the Lactating Mother: Influence on the Trace Element Content of Milk. Acta Paediatr Suppl. 1999;88(430):713.

7. Ejezie FE, Nwagha UI, Ikekpeazu EJ, Ozoemena OFN, Onwusi EA. Assessment of Iron Content of Breast Milk in Preterm and Term Mothers in Enugu Urban. Ann Med Heal Sci Res. 2011;1(1):85-90.

8. Ernawati F, Puspitasari DS, Herman S. Perbedaan Kadar Zat Besi ASI pada Ibu Menyusui Anemia dan Tidak Anemia. PGM. 2007;30(1):8-12.

9. Sekartini R, Oedjatmiko O, Wawolumaya C, Yuniar I, Dewi R, Nycane N, et al. Prevalensi Anemia Defisiensi Besi pada Bayi Usia 4-12 Bulan di Kecamatan Matraman dan Sekitarnya, Jakarta Timur. Sari Pediatri. 2005;7:2-8.

10. Ikatan Dokter Anak Indonesia (IDAI). Rekomendasi Ikatan Dokter Anak Indonesia: Suplementasi Besi Untuk Anak. Jakarta: Badan Penerbit IDAI; 2011.

11. Gunadi D, Lubis B, Rosdiana N. Terapi dan Suplementasi Besi pada Anak. Sari Pediatri. 2009;11(3):207-11 . 
12. Kementerian Kesehatan RI, Direktorat Gizi Masyarakat. Pedoman Pencegahan dan Penanggulangan Anemia pada Remaja Putri dan Wanita Usia Subur (WUS). Jakarta: Kementerian Kesehatan RI; 2016.

13. WHO. Haemoglobin Concentrations for the Diagnosis of Anaemia and Assessment of Severity. 2011. Diunduh dari: http://www. who.int/vmnis/indicators/haemoglobin.pdf, tanggal 8 Oktober 2020.

14. Kanazawa M, Yoshiike N, Osaka T. Criteria and Classification of Obesity in Japan and Asia-Oceania. Asia Pac J Clin Nutr. 2002;11:732-7.

15. Cai C, Harding SV, Friel JK. Breast Milk Iron Concentrations may be Lower than Previously Reported: Implications for Exclusively Breastfed Infants. Matern Pediatr Nutr J. 2015;2(1):2-5.

16. Koreti S, Prasad N. Micronutrient Content of Breast Milk; Review Article. J Evol Med Dent Sci. 2014;3(7):1633-8.

17. Shashiraj, Faridi M, Singh O, Rusia U. Mother's Iron Status, Breastmilk Iron and Lactoferrin - Are They Related?. Eur J Clin Nutr. 2006;60:903-8.

18. Fernández-sánchez $M L$, De RR, St $F$, González H, López-sastre JB, Fernándezcolomer B, et al. Iron Content and its Speciation in Human Milk from Mothers of Preterm and Full-term Infants at Early Stages of Lactation: A Comparison with Commercial Infant Milk Formulas. Microchem J. 2012;105:108-14.

19. Hamdiyah. Perbedaan Konsentrasi Zinc pada Air Susu Ibu antara Status Gizi Baik dan Kurang Energi Kronik Postpartum.
Tesis. Makassar: Sekolah Pascasarjana Universitas Hasanuddin, 2017.

20. Committee on Nutritional Status During Pregnancy and Lactation Institute of Medicine. Nutrition During Lactation. Washington, D.C.: National Academy Press; 1991.

21. Rasmussen KM. The Influence of Maternal Nutrition on Lactation. Annu Rev Nutr. 2014;12:103-17.

22. Ongosi AN. Nutrient Intake and Nutrition Knowledge of Lactating Women (0-6 Months Postpartum) in A Low Socio-Economic Area in Nairobi, Kenya. Dissertation. Pretoria: University of Pretoria, 2010.

23. Nikniaz L, Mahdavi R, Gargari BP, GayemSJ, Nikniaz Z. Maternal Body Mass Index, Dietary Intake and Socioeconomic Status: Differential Effects on Breast Milk Zinc, Copper, and Iron Content. Heal Promot Perspect. 2011;1(2):140-6.

24. Zaidan HK, Al-Terehi M, Mamoori AMJAL, Al-Shuhaib MBS, Al-Saadi AH, Gathwan $\mathrm{KH}$. Detection Some Trace Elements in Human Milk and Effect of Some Factors on its Concentrations. J Biol Med Sci. 2013;1:612.

25. Kumar A, Rai AK, Basu S, Dash D, Singh JS. Cord Blood and Breast Milk Iron Status in Maternal Anemia. Pediatrics. 2008;121(3):e673-7.

26. Shrimpton R, Victora CG, Onis M De, Lima C, Blo M. Worldwide Timing of Growth Faltering: Implications for Nutritional Interventions. Pediatrics. 2001;107(5): e473-80. 
27. Villalpando S, Latulippe ME, Rosas G, Irurita MJ, Picciano MF, O'Connor DL. Milk Folate but not Milk Iron Concentrations may be Inadequate for Some Infants in ARural Farming Community in San Mateo, Capulhuac, Mexico. Am J Clin Nutr. 2003;78:782-9.
28. Asakura K, Sasaki S, Murakami K, Takahashi Y, Uenishi K, Yamakawa M, et al. Iron Intake does not Significantly Correlate with Iron Deficiency among Young Japanese Women : A Cross-Sectional Study. Public Health Nutr. 2008;12(9):1373-83. 